\title{
Initiating the Plea Bargaining: An Effort to Optimize the Return of State Financial Losses on Corruption
}

\author{
Febby Mutiara Nelson ${ }^{1}$, Lushiana Primasari ${ }^{2}$, Emiliya Febriyani $^{3}$ \\ \{feby.mutiara@ui.ac.id ${ }^{1}$ \} \\ Faculty of Law, Universitas Indonesia, 16424, Indonesia ${ }^{1,2,3}$
}

\begin{abstract}
The current orientation of law enforcers is still focused on punishing corruptors with imprisonment, while the return of state financial losses due to corruption is not optimal in its implementation. This study aims to examine the paradigm shift of sentencing in corruption which focuses on recovering state losses and their implementation. The paradigm shift of sentencing in several countries in the world has now shifted, including the application of the Plea Bargaining and Deferred Prosecution Agreement (DPA) by several countries, but in this article, the discussion will focus on Plea Bargaining. This research is legal research with document analysis and uses comparative legal methods. The United States and Pakistan were selected as comparison countries because the United States was the earliest country to implement Plea Bargaining, implemented many Plea Bargaining in its criminal justice system and, had many studies on Plea Bargaining, while Pakistan was chosen as a comparison because it is a country that has implemented Plea Bargaining in the criminal justice system as an effort to optimize the return of state financial losses. This article will discuss the possibility of Indonesia implementing Plea Bargaining in law enforcement against corruption to optimize the return of state financial losses due to corruption
\end{abstract}

Keywords: Corruption; sentencing; plea bargaining

\section{Introduction}

Corruption in a large number has caused major problems, not only for Indonesia but also for countries in the world. Corruption occurs in various sectors, both in the executive, legislative, and judiciary and even in the private sector. Corruption causes losses to the state's finances or the country's economy and hinders national development. Widespread and systematic corruption that results in the social and economic rights of the community. Therefore, the eradication of corruption is one of the main focuses of the Indonesian government.

In particular, the eradication of corruption is regulated in Law No. 31 of 1999 on Corruption Eradication, as amended by Law No. 20 of 2001 concerning Amendments to Law No. 31 of 1999. The Corruption Act regulates imprisonment and fines that can be imposed on perpetrators of corruption. Threats imposed on perpetrators of corruption range from imprisonment of at least 1 year in prison, up to 20 years in prison, to a maximum imprisonment of life. Fines, ranging from a minimum fine of Rp. 50,000,000.00 and a maximum of Rp. 1,000,000,000.00. Even for corruption cases committed in "certain circumstances", the perpetrator is punishable by capital punishment. Additional penalties in the form of replacement money are also regulated $[1]$. 
From the data submitted by Indonesia Corruption Watch, the tendency of judges to impose convictions on perpetrators of corruption in Indonesia is not severe. This can be seen in Table 1.

Table 1. Average trend of corruption judge's decisions 2016-2019 [2] [3].

\begin{tabular}{cllll}
\hline Year & $\begin{array}{c}\text { Average } \\
\text { Punishment }\end{array}$ & District Court & Appeal Court & Supreme Court \\
\hline 2016 & 2 Years 2 Months & 1 Years 11 Months & 2 Years 6 Months & 4 Years 1 Months \\
2017 & 2 Years 2 Months & 2 Years 1 Months & 2 Years 2 Months & 5 Years \\
2018 & 2 Years 5 Months & 2 Years 3 Months & 2 Years 8 Months & 5 Years 9 Months \\
2019 & 2 Years 7 Months & 2 Years 6 Months & 3 Years 8 Months & 3 Years 8 Months \\
\hline
\end{tabular}

From this Table 1, it can be seen that the average decision at each court level from 2016 to 2019 is not much different. Every year the average prison sentence for corruptors is 2 years and 4 months. The difference is in the average verdict at each court level, where the average heaviest decision occurs at the Supreme Court. The data also shows that although the Law on the Eradication of Corruption has provided room for harsh penalties for corruptors, the average punishment given is very light.

In addition, the fines imposed on corruptors are far from the amount of state financial losses caused by corruption. In 2019 alone, for example, state losses incurred as a result of corrupt practices amounted to IDR 12,002,548,977,762.00. Meanwhile, the verdict of the judge who sentenced him to a fine was Rp. 116,483,500,000.00 and additional substitute money was only $\mathrm{Rp} 748.163 .509 .055$ [3]. As a result, less than 10 percent of the state finances can be returned through decisions at various court levels. These conditions indicate that law enforcement against perpetrators of criminal acts of corruption in Indonesia has not been effective.

In its development, incarceration as a sanction has more negative aspects than positive aspects. The negative aspects that arise from the imposition of the deprivation of liberty are, among others, stigmatization and require a lot of resources. Prison or the term according to the language of legislation is called a correctional institution, can be deemed to have failed to carry out its function with a standard of recidivism and / or reconviction [4]. In addition, another negative aspect is the exhausted energy of law enforcers and state budgets to focus on physical punishment for criminals rather than on restoring the consequences of crimes committed. Whereas in many criminal cases, especially corruption, the negative consequences or losses incurred by a crime are more important to repair than depriving the perpetrator of the crime [5]. It takes a systematic and comprehensive effort to recover the consequences of corruption. For this reason, one of the efforts offered is to use a Plea-Bargaining mechanism.

In brief, it can be explained that Plea Bargaining is an exchange of rights offered by law enforcers in exchange for a confession of the defendant's guilt. This exchange can be in the form of a sentence imposed by a court or the size of a criminal charge filed by the public prosecutor. But can Plea Bargaining be applied in Indonesia? Are there other countries that have successfully implemented Plea Bargaining to optimize the return of state losses due to criminal acts of corruption? This is interesting to study further.

This study aims to examine the paradigm shift of punishment in the criminal act of corruption which focuses on recovering state losses and how the possibility of Indonesia to apply Plea Bargaining in law enforcement against corruption to optimize the return of state financial losses due to corruption. 


\section{Method}

This research is doctrinal and uses comparative legal methods. The method in this doctrinal research uses secondary data from regulations, books, and journal articles. Data from the internet is also used as an additional source to complement the data.

A comparative law approach is used to answer research problems. The United States and Pakistan were selected as comparison countries, because the United States was the country that was among the earliest to implement Plea Bargaining, implemented many Plea Bargaining in its criminal justice system and had many studies on Plea Bargaining, while Pakistan was chosen as a comparison because it is a country that has implemented Plea Bargaining in the criminal justice system is an effort to optimize the return of state financial losses.

\section{Results and Discussion}

\subsection{Results}

According to Black's Law Dictionary "Plea bargaining is a negotiated agreement between a prosecutor and a criminal defendant whereby the defendant pleads guilty to a lesser offense or to one of multiple charges in exchange for some concession by the prosecutor; a more lenient sentence or a dismissal of the other charges. Also termed plea agreement; negotiated plea; sentence bargain" [6].

Meanwhile, in the implementation of plea bargaining "In the plea bargain arrangement considered herein, the prosecution determines the plea offer (the reduced punishment under the plea bargain) and is committed to send to trial those that reject the offer, giving rise to the latter (defendant-judge) interaction" [7]. Therefore, the main actors in the implementation of plea bargaining are the Public Prosecutor and the Defendant (or his lawyer). Whereas here the role of the public prosecutor in proving his accusation is faced with the voluntary process of the defendant to admit his mistake so that there is convenience for the public prosecutor in processing a case. Here there is an actual concession, where the public prosecutor finds it easier in the process of proving the indictment, while the suspect gets relief in terms of his sentence.

Plea Bargaining is made with a plea guilty from the defendant in exchange for commuted indictment and / or commuted criminal charges. With this process, judges no longer carry out examinations at trial and can immediately impose penalties. Therefore, plea bargaining is considered cost effective and reduces the burden on the prosecutor's office and the court. Plea bargaining is a concept whose origins have existed since the 18th century in England and the 19th century in the United States even though at that time what developed was not plea bargaining but guilty pleas. In the decades following the 1920's, American criminal courts became even more dependent on the guilty plea [8].

\subsection{Discussion}

\subsubsection{The Paradigm Shift of Sentencing in Corruption which Focuses on Recovering State Financial Losses}

As a comparison, let's look at the practice of bargaining in the US and Pakistan. The regulations regarding plea bargaining in the United States are regulated in the Federal Rules of 
Criminal Procedures, Rule 11 [9]. which prohibits the court from accepting a guilty plea without first hearing the defendant's statement regarding whether the confession he made was voluntary and not due to pressure or coercion or other promises given by the public prosecutor outside of the Plea Agreement. According to a study from the Pew Research Center, of the roughly 80,000 federal prosecutions initiated in 2018, just two percent went to trial. More than 97 percent of federal criminal convictions are obtained through plea bargains, and the states are not far behind at 94 percent [10]. The application of plea bargaining in the United States has made criminal justice in the United States effective and efficient so that criminal justice in the United States is able to prevent high costs and long time in the criminal justice process.

How about the application of plea bargaining in Pakistan? Plea bargaining as a formal legal provision was introduced in Pakistan in the 1999 National Accountability Ordinance (NAO), an anti-corruption law. Its particular feature is that the defendant filed a petition, accepted guilt, and offered to return the proceeds of corruption as determined by the prosecutor's investigator. One case that applies the Plea-Bargaining concept in Pakistan is the accused Harish in the Thatta Water Supply case. The accused, in his petition, said that he had returned the money and the Chairman of the National Accountability Bureau (NAB) had accepted his request. Harish, who was accused, asked the court to grant his defense in the case [11].

\subsubsection{The Opportunity of Indonesia Implementing Plea Bargaining in Law Enforcement Against Corruption to Optimize the Return of State Financial Losses Due To Corruption}

From the comparative study of the law on the application of plea bargaining in the US and Pakistan, it turns out that there are practices in other countries and it is successful, can this be applied in Indonesia? Indonesia can apply plea bargaining, this can be seen in several provisions, namely Article 82 of the Criminal Code, which currently exists but is limited to violations that are only punishable by fines. We can also find in Article 152 letters e and fof the Draft Criminal Code concerning the loss of authority to sue if there is a settlement outside the process which reinforces the provisions of Article 82 of the Criminal Code, namely afdoening buiten proces, but it is more broadly enforced, not only for violations, and not only for those who are threatened with a fine, but also those which are threatened with imprisonment (so it is similar to the transactive provisions in the current Dutch Criminal Code). Another example is diversion (transfer of children's cases out of the court process) for children in conflict with the law (juvenile delinquency) which is regulated in Law Number 12 the Year 2011 concerning the Juvenile Criminal Justice System. Other examples of mechanisms that have been implemented in Indonesia are the Master Settlement and Acquisition Agreement (MSAA) and the Master Refinancing and Note Issuance Agreement (MRNIA) carried out by the government in the case of Bank Indonesia Liquidity Assistance (BLBI Case).

Based on these considerations, several things that must be considered if Indonesia will implement Plea Bargaining, are: [12]

- The use of the term is not plea bargaining but Persetujuan Mengaku Bersalah (PMB) in accordance with the context of the Indonesian criminal justice system and in accordance with simple, fast and low cost judicial principles.

- Regulated in statutory regulations. If the plea bargaining is an opportunity to be implemented in Indonesia in the future, of course there must be regulation in the form of statutory regulations either regulated by a separate law, or regulated in law, for example included in the Criminal Procedure Code, so that law enforcers have legality 
in carrying out this, and not solely at the discretion of the prosecutor or the Corruption Eradication Commission (KPK).

- Involves the criminal justice system. In addition to the public prosecutor or KPK and the defendants / lawyers, there are other parties involved in the plea-bargaining process, namely the involvement of the Audit Board of the Republic of Indonesia (BPK) as an auditor who will calculate the value of state financial losses, the value of compensation and fines to be paid. By the accused. Another party involved in this process is an independent judge in the negotiation process.

- There are special conditions or things that are negotiated in Plea Bargaining and criminal acts that can be negotiated in plea bargaining, only that focus on recovering state financial losses, namely criminal acts in the economic sector, for example corruption, money laundering.

- Revise the Draft Criminal Procedure Code (RKUHAP), because the current RKUHAP is not suitable for plea bargaining and changes the concept of "special path" in the RKUHAP, because the "special path" in this RKUHAP is different from the PleaBargaining concept where bargaining is carried out before the trial is held, not when the trial has been running as intended "special path" in RKUHAP.

\section{Conclusion}

The paradigm shift of sentencing in corruption should shift from the retributive justice paradigm to the paradigm of punishment which focuses on recovering state financial losses, one of which is through the plea-bargaining mechanism. In the future, Indonesia has the opportunity to apply plea bargaining in law enforcement against corruption to optimize the return of state financial losses due to corruption by applying several criteria, there are: The use of the Plea Bargaining term, not plea bargaining but Persetujuan Mengaku Bersalah (PMB); Regulated in statutory regulations; Involves the criminal justice system; Specify special requirements; and Revise the Draft Criminal Prosedure Code (RKUHAP).

\section{Acknowledgment}

The researcher would like to thank the Directorate of Research and Community Engagement at the University of Indonesia because this research funding by PUTI Research Grant 2020.

\section{References}

[1] The Governtment of Indonesia, "the Amendment of Law No. 31 of 1999 Eradication of Corruption," pp. 1-20, 1999, [Online]. Available: http://peraturan.go.id/common/dokumen/ln/2001/uu202001.pdf.

[2] Indonesia Corruption Watch (ICW), "Catatan Pemantauan Perkara Korupsi yang Divonis oleh Pengadilan Selama 2018: Koruptor Belum Dihukum Maksimal,” 2018. [Online]. Available: https://antikorupsi.org/sites/default/files/narasi_tren_vonis_2018.pdf. 
[3] Indonesia Corruption Watch (ICW), "Catatan ICW Tren Vonis Pengadilan Tindak Pidana Korupsi Selama 2019 Vonis Tanpa Efek Jera,” 2019. [Online]. Available: https://www.antikorupsi.org/sites/default/files/dokumen/narasi_tren_vonis_2019.pdf.

[4] M. P. Gunarto, "Sikap memidana yang berorientasi pada tujuan pemidanaan," Mimbar. Hukum., vol. 21, no. 1, p. 94, 2009.

[5] Y. Piadi and R. I. Sitepa, "Implementasi Restoratif Justice dalam Pemidanaan Pelaku Tindak Pidana Korupsi,” J. Rechten Ris. Huk. dan Hak Asasi Mns., vol. 1, p. 2, 2019.

[6] B. A. Garner, "Black' S Law Dictionary," West Publ. Co., p. 1074, 1968.

[7] Y. Tsur, "Bounding reasonable doubt : implications for plea bargaining," Eur. J. Law Econ., vol. 44, no. 2, pp. 197-216, 2017, doi: 10.1007/s10657-016-9554-z.

[8] A. W. Alschuler, "Plea Bargaining and Its History COLUMBIA LAW REVIEW," vol. 1, 1979.

[9] J. Vile, D. Hudson, and J. Vile, "Federal Rules of Criminal Procedure, Rule 41," Encycl. Fourth Amend., 2014, doi: 10.4135/9781452234243.n267.

[10] Clark Neily, "Prisons are packed because prosecutors are coercing plea deals. And, yes, it's totally legal.," 9 August 2019. https://www.nbcnews.com/think/opinion/prisons-are-packed-becauseprosecutors-are-coercing-plea-deals-yes-ncna1034201 (accessed Feb. 27, 2021).

[11] Pakistan Today, "Court grants plea bargain to accused in corruption reference," 2nd August, 2019. https://www.pakistantoday.com.pk/2019/08/02/court-grants-plea-bargain-to-accused-in-corruptionreference/.

[12] F. M. Nelson, Plea Bargaining \& Deferred Prosecution Agreement Dalam Tindak Pidana Korupsi. Sinar Grafika, 2020. 